\title{
Genetic factors affecting statin concentrations and subsequent myopathy: a HuGENet systematic review
}

\author{
William J. Canestaro, MSc ${ }^{1}$, Melissa A. Austin, PhD, MS² and Kenneth E. Thummel, PhD ${ }^{3}$
}

Statins, 3-hydroxy-3-methyl-glutaryl-coenzyme A reductase inhibitors, have proven efficacy in both lowering low-density-lipoprotein levels and preventing major coronary events, making them one of the most commonly prescribed drugs in the United States. Statins exhibit a class-wide side effect of muscle toxicity and weakness, which has led regulators to impose both dosage limitations and a recall. This review focuses on the best-characterized genetic factors associated with increased statin muscle concentrations, including the genes encoding cytochrome P450 enzymes (CYP2D6, CYP3A4, and CYP3A5), a mitochondrial enzyme (GATM), an influx transporter (SLCO1B1), and efflux transporters $(A B C B 1$ and $A B C G 2)$. A systematic literature review was conducted to identify relevant research evaluating the significance of genetic variants predictive of altered statin concentrations and subsequent statin-related myopathy. Studies eligible

\section{BACKGROUND}

Disease

Inhibitors of 3-hydroxy-3-methyl-glutaryl-coenzyme A (HMG$\mathrm{CoA}$ ) reductase, commonly known as statins, comprise the cornerstone of treatment for hyperlipidemia ${ }^{1}$ and have proven efficacy in lowering both low-density-lipoprotein cholesterol levels and the risk of subsequent major coronary events. ${ }^{2,3}$ Because of their efficacy and presumed innocuous side-effect profile, statins are used by nearly 20 million adults in the United States and had more than $\$ 20$ billion in global sales in $2011 .^{4}$

Despite the fact that this class of drugs is generally believed to have a favorable side-effect profile, a class-wide side effect comprising muscle toxicity and weakness has spurred regulators to impose both dosage limitations and a recall to protect patient safety. ${ }^{5,6}$ The most recognizable example of this is the drug cerivastatin, which was recalled from the US and European markets in 2001 and 2002, respectively, by its manufacturer, Bayer, due to its risk of rhabdomyolysis (the most extreme form of myopathy) and consequent deaths. ${ }^{5}$ More recently, in 2010, the US Food and Drug Administration placed new restrictions on the highest dose of the drug simvastatin due to its risk of myopathy and rhabdomyolysis. ${ }^{6,7}$ Furthermore, recent evidence suggests that the risk of myopathy seems to occur along a gradient in the statin class, with more lipophilic statins such as simvastatin carrying a higher overall risk. ${ }^{8}$ A review of the pharmacological for inclusion must have incorporated genotype information and must have associated it with some measure of myopathy, either creatine kinase levels or self-reported muscle aches and pains. After an initial review, focus was placed on seven genes that were adequately characterized to provide a substantive review: $C Y P 2 D 6, C Y P 3 A 4, C Y P 3 A 5$, GATM, SLCO1B1, ABCB1, and ABCG2. All statins were included in this review. Among the genetic factors evaluated, statin-related myopathy appears to be most strongly associated with variants in SLCO1B1.

Genet Med advance online publication 8 May 2014

Key Words: muscle toxicity; myopathy; pharmacogenomics; SLCO1B1; statins

characteristics of these statins (Table 1) shows the diversity in the manner in which these drugs are metabolized. ${ }^{9}$

It is difficult to quantify the precise burden of myopathy due largely to its heterogeneous clinical presentation and the fact that there is no universally agreed-upon definition used for diagnosis. ${ }^{10}$ Myopathy is thought to occur across a spectrum of severity. At one end of the spectrum is myalgia, defined as muscle cramps or weakness without elevated serum levels of creatine kinase (CK: it is an enzyme marker of muscle breakdown that is used as a surrogate to quantify the amount of total muscle damage). Rhabdomyolysis, a rare event at the other end of the spectrum, is the breakdown of muscle tissue to such a degree that it can cause renal failure and even death. ${ }^{10}$ Commonly used thresholds for diagnosing myopathy are presented in Table 2.

Furthermore, although statin-related myopathy (SRM) may be less severe than statin-related rhabdomyolysis, it has important consequences for patients. Research has shown that side effects of statins, either clinically defined or patient perceived, are causes of both discontinuation of treatment and switching of drugs. ${ }^{11-13}$ Results from the USAGE (Understanding Statin Use in America and Gaps in Patient Education) study, an Internet-based survey of $>10,000$ statin users, exemplified this problem. Among participants, 29\% experienced muscle-related side effects. Furthermore, of those participants who discontinued their medication due to a side effect, $33 \%$ did so without consulting their physician. ${ }^{14}$ This implies that patients may be

${ }^{1}$ Pharmaceutical Outcomes Research and Policy Program, School of Pharmacy, University of Washington, Seattle, Washington, USA; ${ }^{2}$ Department of Epidemiology, School of Public Health, University of Washington, Seattle, Washington, USA; ${ }^{3}$ Department of Pharmaceutics, School of Pharmacy, University of Washington, Seattle, Washington, USA. Correspondence: Melissa A. Austin (maustin@uw.edu) 
Table 1 Characteristics of statin drugs

\begin{tabular}{|c|c|c|c|c|c|c|c|c|}
\hline Drug characteristic & Atorvastatin & Fluvastatin & Cerivastatin & Lovastatin & Pitavastatin & Pravastatin & Rosuvastatin & Simvastatin \\
\hline Year approved & 1996 & 1993 & $\begin{array}{l}1997 \\
\text { recalled in } 2001\end{array}$ & 1987 & 2009 & 1991 & 2003 & 1991 \\
\hline Generic available & Yes & Yes & No & Yes & No & Yes & No & Yes \\
\hline $\begin{array}{l}\text { Approved daily } \\
\text { dosage (mg) }\end{array}$ & $10-80$ & $20-80$ & $0.2-0.3$ & $20-80$ & 2 & $20-80$ & $10-40$ & $10-40$ \\
\hline $\begin{array}{l}\text { Genes involved in } \\
\text { first-pass metabolism }\end{array}$ & CYP3A4 & CYP2C9 & $\begin{array}{l}\text { CYP3A4, } \\
\text { CYP2C8 }\end{array}$ & CYP3A4 & CYP2C9 & $\begin{array}{c}\text { Multiple, } \\
\text { primarily CYP3A4 }\end{array}$ & CYP2C9 & CYP3A4 \\
\hline Hepatic excretion (\%) & $>70$ & $>68$ & 70 & $>70$ & 90 & $45-71$ & $63-90$ & $58-97$ \\
\hline Renal excretion (\%) & 2 & 6 & $<30$ & $<30$ & $<10$ & $20-60$ & 10 & 13 \\
\hline
\end{tabular}

aplease refer to Table 3 for more information on these genes.

Table 2 Definitions of myopathy

\begin{tabular}{llll}
\hline Clinical entity & \multicolumn{1}{c}{ ACC/AHA/NHLBI } & \multicolumn{1}{c}{ FDA } & NLA \\
\hline Myopathy & $\begin{array}{l}\text { Umbrella definition for any disease } \\
\text { of muscles }\end{array}$ & CK $\geq 10$ times ULN & $\begin{array}{l}\text { Muscle pain, soreness, weakness, or cramps and CK } \\
\text { elevation }>10 \text { times ULN }\end{array}$ \\
Myalgia & $\begin{array}{l}\text { Muscle pain or weakness without } \\
\text { CK elevation }\end{array}$ & N/A & N/A \\
Myositis & $\begin{array}{l}\text { Muscle symptoms with CK elevation } \\
<10 \text { times ULN }\end{array}$ & N/A & N/A \\
Rhabdomyolysis & $\begin{array}{l}\text { Muscle symptoms with CK elevation } \\
\geq 10 \text { times ULN and creatine elevation }\end{array}$ & $\begin{array}{l}\text { CK }>50 \text { times ULN and } \\
\text { evidence of organ damage }\end{array}$ & $\begin{array}{l}\text { CK }>10,000 \text { IU/l or }>10 \text { times ULN plus an elevation in } \\
\text { serum creatine or medical intervention with i.v. hydration }\end{array}$ \\
\hline
\end{tabular}

Table adapted from ref. 10.

ACC, American College of Cardiology; AHA, American Heart Association; CK, creatine kinase; FDA, US Food and Drug Administration; N/A, not available; NHLBI, National Heart, Lung, and Blood Institute; NLA, National Lipid Association; ULN, upper limit of normal.

losing the cardioprotective effect of statin therapy due to these side effects. In fact, the true burden may be hard to estimate because patients who discontinue may do so outside the healthcare system.

Although the exact prevalence of SRM is unclear, adverse event reporting suggests that it is much more common than initially suspected from clinical trials. Randomized clinical trials of high-dose statin therapy generally report a cumulative myopathy incidence of $1-3 \%$ over the length of the study. ${ }^{15}$ These trials may be biased toward low event rates because they use run-in periods to screen out patients with early intolerance and have stringent criteria for the definition of SRM. In analyses that use a more inclusive definition and incorporate patient-reported outcomes, the cumulative incidence of SRM can be as high as $10-25 \%$ of patients. ${ }^{8,14}$ If these numbers are accurate, these findings suggest that SRM may affect $\sim 2-5$ million patients in the United States annually.

The exact etiology of SRM is also unclear. Many potential mechanisms have been hypothesized, including reduced production of coenzyme Q10 or ubiquinone, increased cholesterol uptake, changes in the metabolism of fat, decreased myolemma, failure to restore damaged protein in skeletal muscle, decreased prenylated protein production and phytosterols, disrupted metabolism of calcium in muscle tissue, decreased sarcoplasmic reticular cholesterol, and inhibition of selenoprotein synthesis. ${ }^{16}$ Despite this uncertainty, it is universally accepted that SRM is a dose/exposure-dependent, ${ }^{15,17}$ genetically influenced $^{18}$ phenomenon. However, there are no heritability estimates available because there is controversy over whether this method can be reliably applied to pharmacogenomic traits. ${ }^{19,20}$

This review will focus on the absorption, distribution, metabolism, and excretion (ADME) of statins and on genetic loci that have been shown to have consistent pharmacokinetic and subsequent effects on clinically defined myopathy events.

\section{GENES AND GENE VARIANTS}

The genes that have been best characterized with regard to the ADME of statins fall into four classes and encode cytochrome P450 enzymes (CYP2D6, CYP3A4, and CYP3A5), the mitochondrial enzyme glycine amidinotransferase (GATM), cell influx transporters (SLCO1B1), and cell efflux transporters ( $A B C B 1$ and $A B C G 2$ ). Each of these is described in detail below and in Table 3.

\section{Cytochrome P450 enzymes: CYP2D6, CYP3A4, and CYP3A5}

The cytochrome P450 family is a diverse group of 30 known isoenzymes responsible for catalyzing the oxidation of organic endogenous and xenobiotic compounds. Taken together, these enzymes comprise the most important enzyme system for phase I metabolism and have been estimated to account for $75 \%$ of all drug bioactivation and metabolic reactions. ${ }^{21,22}$ The majority of cytochrome-mediated reactions are primarily 
Table 3 Genes that influence absorption, distribution, metabolism, and excretion of statins

\begin{tabular}{|c|c|c|c|c|}
\hline Gene & Protein & Location & $\begin{array}{l}\text { Reduced-function } \\
\text { allele(s) }\end{array}$ & Coding variation(s) \\
\hline \multirow[t]{3}{*}{ CYP2D6 } & \multirow{3}{*}{$\begin{array}{l}\text { Cytochrome P450, family 2, subfamily D, } \\
\text { polypeptide } 6 \text { (CYP2D6) }\end{array}$} & \multirow[t]{3}{*}{$22 q 13.1$} & *3 & 259Frameshift \\
\hline & & & *4 & P34S; L91M; H94R; splicing defect \\
\hline & & & *5 & Deletion \\
\hline СYPЗА4 & $\begin{array}{l}\text { Cytochrome P450, family 3, subfamily A, } \\
\text { polypeptide } 4 \text { (CYP3A4) }\end{array}$ & $7 q 21.1$ & *1B & A-392G \\
\hline \multirow{2}{*}{ СYРЗА5 } & \multirow{2}{*}{$\begin{array}{l}\text { Cytochrome P450, family 3, subfamily A, } \\
\text { polypeptide } 5 \text { (CYP3A5) }\end{array}$} & \multirow{2}{*}{$7 q 21.1$} & $\star 3 B$ & $\begin{array}{l}\text { 3705C }>T ; 3709 \_3710 \text { insG; } \\
\text { 6986A>G; 31611C>T }\end{array}$ \\
\hline & & & $\star 3 C$ & $6986 A>G$ \\
\hline \multirow[t]{2}{*}{ SLCO1B1 } & \multirow{2}{*}{$\begin{array}{l}\text { Organic anion-transporting polypeptide } \\
\text { 1B1 (OATP1B1) }\end{array}$} & \multirow[t]{2}{*}{$12 \mathrm{p} 12.2$} & *5 & $521 \mathrm{~T}>\mathrm{C}$ \\
\hline & & & *15 & $521 \mathrm{~T}>\mathrm{C} ; 388 \mathrm{~A}>\mathrm{G}$ \\
\hline
\end{tabular}

ATP, adenosine triphosphate.

catalyzed via CYP2D6 (cytochrome P450, family 2, subfamily D, polypeptide 6) and CYP3A4/5 (cytochrome P450, family 3, subfamily A, polypeptide 4/5), and statins are no exception. ${ }^{23}$ All these enzymes have variations in their respective predicate genes that can affect their drug-metabolizing rates. ${ }^{16}$

The CYP2D6 gene, located at chromosome 22q13.1, encodes the synonymous protein and is one of the most polymorphic genes in the cytochrome family, with $>50$ characterized alleles. ${ }^{24}$ These alleles have phenotypic effects on the rate of metabolism, allowing patients to be categorized as poor, intermediate, extensive, or ultrarapid metabolizers, based on whether they have severely reduced, somewhat reduced, normal, or increased rates of metabolism, respectively. Although $>100$ variants in CYP2D6 have been identified and at least 15 of these are known to confer reduced function, only three alleles account for the majority of poor metabolizers- ${ }^{*} 3,{ }^{*}$, and ${ }^{*}$. In the context of statins, poor metabolizers are the most important group due to the higher concentrations of statins in patient plasma ${ }^{25-27}$ and, consequently, higher rates of adverse events..$^{28,29}$ Furthermore, the prevalence of the poor metabolizer phenotype is known to vary dramatically by ethnic group, from roughly $5-10 \%$ among Caucasians, $2 \%$ among blacks, to $<1 \%$ in Asians. ${ }^{30}$

The CYP3A4 gene encodes a synonymous protein and is located on chromosome 7q21.1. Unlike several other cytochrome P450 genes, CYP3A4 has no well-characterized null alleles. Variation in the $5^{\prime}$-flanking region is thought to influence transcript level and function, but complete messenger RNA has been found in every patient studied to date. ${ }^{31}$ Of the five different single-nucleotide polymorphisms (SNPs) identified in the $5^{\prime}$-flanking region, the most common is A-392G $\left({ }^{*} 1 B\right)$, which has a variable allele frequency by ethnic group ${ }^{31,32}$ : $0 \%$ among Chinese, ${ }^{33}$ Taiwanese, ${ }^{34}$ and Chinese and Japanese Americans $^{35}$; 2-10\% among Caucasians ${ }^{34-37}$; 9-11\% among Hispanics $^{35,38}$; and $35-65 \%$ among African Americans. ${ }^{32,34,35,39}$
Although changes in the coding region of this gene have been identified, the allele frequency is so low $(<5 \%)$ that no homozygotes have been reported. Thus, these SNPs are not believed to have a large impact on phenotypic differences at a population level. ${ }^{31}$ Of note, recent evidence also suggests the importance of the ${ }^{\star} 22$ SNP in intron 6 of CYP3A4 (rs35599367), which is relatively common (minor allele frequency of 3-8\%) and has been shown to increase hepatic expression by up to sixfold. ${ }^{40,41}$ This evidence is relatively preliminary and will need to be replicated within larger samples.

The CYP3A5 gene is located in close proximity to the CYP3A4 gene on chromosome $7 \mathrm{q} 21.1$, and the two have many variants in linkage disequilibrium with each other. The most important SNP in 3A4, A6986G, results in a splicing defect and subsequent low levels of protein translation. ${ }^{31}$ This variation, in combination with other SNPs, forms the ${ }^{*} 3 A,{ }^{*} B B$, and ${ }^{*} \mathrm{C}$ alleles. The ${ }^{*} 3$ allele is very common across populations, with allele frequencies of $85-95 \%$ among Caucasians, ${ }^{36,42}$ 27-55\% among African Americans, ${ }^{36,42}$ 27\% among Chinese, ${ }^{42}$ $30 \%$ among Koreans, ${ }^{42}$ 25\% among Mexicans, ${ }^{36}$ 15\% among Japanese, ${ }^{36}$ and $60 \%$ among Southwestern Native Americans. ${ }^{36}$ The ${ }^{\star} 3$ allele results in reduced metabolism and subsequently causes elevated plasma concentrations for those statins dependent on this enzyme. CYP3A metabolic activity is concentrated in the liver and proximal regions of the small intestine, where it controls the oral bioavailability and systemic clearance of many drugs, including statins. ${ }^{43}$

\section{Mitochondrial enzyme: GATM}

The enzyme GATM (with synonymous gene name) is a mitochondrial protein that catalyzes the rate-limiting step in the biosynthesis of creatine, a recently hypothesized contributor to statin myopathy. ${ }^{44} \mathrm{~A}$ contribution of this mitochondrial enzyme in myopathy seems physiological sound, considering 
the importance of creatine for energy production in skeletal muscle. Currently, the allele frequency for GATM has not been well characterized.

\section{Influx transporter: SLCO1B1}

For statins to be effective in reducing the hepatic synthesis of cholesterol, they must first be transported from the portal blood into the liver across the hepatocellular membrane's phospholipid bilayer. This transport primarily occurs through the actions of the organic anion-transporting polypeptide 1B1 (OATP1B1) influx transporter, which is expressed on the basolateral membrane of human hepatocytes. OATP1B1 is encoded by SLCO1B1 (chromosome 12p12.2), whose ${ }^{*} 5$ and ${ }^{*} 15$ alleles are the best characterized with regard to SRM. The SLCO1B1 ${ }^{* 5}$ allele (Val174Ala, 521T>C) disrupts the localization of the transporter to the plasma membrane, resulting in decreased hepatic uptake, greater systemic plasma concentrations of statins, and hence greater muscle statin exposure. ${ }^{45}$ The allele frequencies of $S L C O 1 B 1^{* 5}$ vary widely, with $1-4 \%$ among African Americans, ${ }^{46,47}<1 \%$ among Japanese, ${ }^{48}$ 6-19\% among non-Japanese Asians, ${ }^{49,50}$ and $12-20 \%$ among Caucasians. ${ }^{46,47,51,52}$ Importantly, the SLCO1B1 ${ }^{\star} 15$ haplotype carries the same $521 \mathrm{~T}>\mathrm{C}$ substitution as $\mathrm{SLCO1B1}{ }^{\star} 5$, in combination with the $388 \mathrm{~A}>\mathrm{G}$ SNP, and represents another risk haplotype for myopathy. The $S L C O 1 B 1^{\star} 15$ allele is relatively common in some Asian populations, with a frequency of $10 \%$ among the Japanese. ${ }^{48}$

\section{Efflux transporters: $A B C B 1$ and $A B C G 2$}

$A B C B 1$ encodes the protein adenosine triphosphate (ATP)binding cassette $(\mathrm{ABC})$ subfamily $\mathrm{B}$ member 1 ( $\mathrm{ABCB} 1$ is also known as P-gp for permeability glycoprotein 1, MDR1 for multidrug resistance protein 1, and CD243 for cluster of differentiation 243) and is an $A B C$ transporter; transport mediated by this protein is an important step in the efflux of lipophilic statins and their metabolites out of the liver. Although its prevalence in the population is unknown, the haplotype 1236T-2677T-3435T of $A B C B 1$ has recently been shown to reduce efflux of simvastatin and atorvastatin (but not other statins), thereby increasing their plasma concentrations. ${ }^{53-55} \mathrm{ABCG} 2, \mathrm{ABC}$ subfamily $\mathrm{G}$ member 2 (also known as BCRP), is an ABC transporter whose 421AA variant has unknown carrier frequency but has been shown to increase plasma concentrations of both atorvastatin and rosuvastatin. ${ }^{56}$

\section{MATERIALS AND METHODS}

For this analysis, all variants in the CYP2D6, CYP3A4/5, SLCO1B1, $A B C B 1$, and $A B C G 2$ genes described above and known to affect statin plasma concentrations were included as search criteria to identify eligible studies. To be considered for inclusion, studies were required to track either differences in pharmacokinetics as measured via AUC (AUC is defined as area under the curve for plasma concentration $\mathrm{AUC}_{0-\infty}$ ng.hour/ml) or some form of muscle toxicity (myalgia, myopathy, or rhabdomyolysis) and to have available genotype information. All types of study designs, including cohort, case-control, and prospectively randomized trials, were included. Although CYP2C9 is an important cytochrome P450 enzyme for understanding drug-drug interaction within the statin class, our literature search did not reveal any studies that evaluated CYP2C9 genotype in relation to SRM. Thus, $C Y P 2 C 9$ was not included in this review.

To identify studies for the review, a literature search was completed via MEDLINE, with a Boolean search string using various combinations of the drugs (statin, HMG-CoA reductase inhibitor, simvastatin, atorvastatin, pravastatin, pitavastatin, rosuvastatin, fluvastatin, and cerivastatin), the genes (CYP2D6, CYP3A4/5, SLCO1B1, GATM, ABCB1, and ABCG2), and the salient outcomes (pharmacokinetics, myalgia, myopathy, and rhabdomyolysis). These results were crossreferenced with the bibliographies of reviews and meta-analyses from another MEDLINE search to identify potentially missing studies. For the purpose of the review, the data extracted included genotype frequency, event rates in allele carriers versus wild-type carriers, and characteristics of the study (design: case-control, cohort, or randomized trial; number of participants; use of control population; clinical and demographic characteristics of the underlying population from which participants were recruited; interventions; and statistical methods used) .

\section{RESULTS}

Overall, 13 studies were identified (listed chronologically in Table 4) that associated genetic variants with some form of the clinical outcome of muscle toxicity and weakness (myalgia, SRM, or statin-related rhabdomyolysis). Because pharmacokinetic studies are easier to perform logistically, many more studies were found that evaluated changes in the surrogate end point of plasma drug concentration rather than the clinically defined end points of interest here. Furthermore, no studies were found that evaluated interactions among genes. Thus, all associations described here are for single genes with the SRM phenotype.

\section{Cytochrome P450 enzymes: CYP2D6, CYP3A4, and CYP3A5}

As mentioned above, cytochrome P450 enzymes are necessary components of first-pass metabolism of the majority of drugs. Therefore, null- or reduced-transcription variations in these genes that reduce the total amount of enzyme available to catalyze metabolic reactions can have strong phenotypic consequences, depending on the fraction of dose metabolized by the polymorphic enzyme. In the case of CYP2D6, three studies evaluated the rate of SRM as a function of genotype. In the study by Frudakis et al., ${ }^{29}$ the frequencies of 388 candidate gene SNPs in a group of previously collected, clinically annotated, and deidentified samples from an ethnically diverse population were investigated. Samples of clinically defined myopathy cases and treatment-matched controls were collected from sites across the United States as part of existing study protocols targeting numerous cardiovascular conditions. The study was designed as a nested case-control investigation, and it compared those exhibiting SRM events on either atorvastatin or simvastatin treatment 
with unaffected controls (75 atorvastatin (atorva) SRM cases, 188 atorva controls; 61 simvastatin (simva) SRM cases, and 188 simva controls). A difference in the CYP2D $6^{\star} 4$ allele frequency was seen for both drugs. However, the relationship was significant only for atorva-treated patients (odds ratio, $\mathrm{OR}=2.5, P<$ $0.001)$ and not for simva-treated patients $(\mathrm{OR}=1.7, P=0.06)$. In the study by Mulder et al., ${ }^{28}$ in which a cohort of patients receiving $40 \mathrm{mg} /$ day simvastatin were genotyped at the CYP2D6 locus, discontinuation for any side effect was significantly higher among homozygous carriers of reduced-function alleles relative to carriers of the wild-type allele (relative risk $=4.7$; although no statistical significance was reported by the study authors, a two-sided Fisher's exact test shows this to be significant at $P<$ 0.01 ). Yet not all studies have validated this relationship. In the study of Zuccaro et al., ${ }^{57} 50$ cases on treatment with five different types of statins were collected from a single high-volume lipid clinic and matched with 50 controls from the same clinic based on age, sex, and pretreatment lipid levels. Ultimately, no difference in genotypes was seen between SRM cases and controls. Potentially, this result could be due to the attenuation of effect by aggregating all statins in the final analysis. Statins are known to have different levels of dependence on CYP2D6 for metabolism and so perhaps any true effect for those statins that are more dependent on this locus might have been lost in the null effect from other loci. Finally, the open-label randomized STRENGTH (Statin Response Examined by Genetic Haplotype Markers) trial (described in greater detail below) also failed to show a significant association with this locus.

CYP3A4 would be hypothesized a priori to have strong influence on rates of SRM. A number of statins, including simvastatin and atorvastatin, are metabolized via CYP3A4, and coprescription of CYP3A4 inhibitors is the greatest risk factor for drugdrug interactions in patients taking statins. ${ }^{31}$ However, only one study, STRENGTH, was identified that evaluated common CYP3A4 variants with myopathy risk. ${ }^{58}$ This study, which randomized patients to ascending doses of atorvastatin, simvastatin, or pravastatin, failed to show an association for the $C Y P 3 A 4^{*} 1 B$ allele with a composite adverse event of discontinuation for any side effect, myalgia, or CK greater than three times the upper limit of normal during follow-up. Finally, for CYP3A5, which is known to have a modest role in the metabolism of atorvastatin, ${ }^{59}$ the results are mixed. In the two previously reported case-control studies ${ }^{29,57}$ that investigated variability at this locus, no significant difference was seen in genotype between SRM cases and controls. In another case-control study conducted within a community lipid practice, no differences in CYP3A4 and CYP3A5 allele frequencies were found. In an exploratory analysis within only the cases, however, the CYP $3 A 5^{*} 3$ allele was associated with the degree of serum CK elevation after controlling for concomitant gemfibrozil and niacin use, known predisposing characteristics for myopathy. ${ }^{60}$

\section{Mitochondrial enzyme: GATM}

Recent evidence has suggested that a SNP (rs1719247) in the GATM gene appears to represent a protective factor for SRM. ${ }^{61}$
Creatine is an essential energy source for skeletal muscle, and a failure to synthesize sufficient amounts has been hypothesized to result in greater susceptibility to SRM. This hypothesis was generated by Mangravite et al. ${ }^{61}$ in a study that first used a whole-genome expression quantitative trait loci analysis with samples from a clinical trial to identify regions of the genome whose expression was modified by exposure to simvastatin. The most strongly associated of these loci, GATM, was then evaluated retrospectively in a population- and trial-based cohort. A meta-analysis of the effect in these two groups showed an OR of 0.60 for the association of this SNP with myopathy as defined by CK elevation and report of pain $(95 \%$ confidence interval: $\left.0.45-0.81, P=6 \times 10^{-4}\right)$. This result presents a novel mechanism for the onset of SRM and merits further research.

\section{Influx transporter: SLCO1B1}

The first analysis to identify an association between SLCO1B1 gene variation and SRM was conducted by the Study of the Effectiveness of Additional Reductions in Cholesterol and Homocysteine (SEARCH) Collaborative Group. ${ }^{62}$ For their analysis, the investigators conducted association studies in exploratory and validation cohorts of patients receiving 80 and $40 \mathrm{mg}$ of simvastatin in the SEARCH and Heart Protection Study trials, respectively. In the SEARCH cohort, the investigators performed a genome-wide association study by screening $\sim 300,000$ genomic variations in 85 cases with clinically defined SRM and 90 controls. A significant association was subsequently identified with a single, noncoding SNP (rs4363657) located within intron 11 of SLCO1B1 $\left(P<5 \times 10^{-9}\right)$. Resequencing of this locus as well as the $10-\mathrm{kb}$ flanking regions showed that it was in nearly complete linkage disequilibrium with 11 SNPs, only one of which was nonsynonymous (the ${ }^{\star} 5$ allele, $521 \mathrm{~T}>\mathrm{C}$, rs4149056). Subsequent analysis showed that patients carrying two copies of the SLCO1B1 ${ }^{\star} 5$ allele had an $18 \%$ cumulative incidence of SRM after 1 year of therapy, $\sim 45$-fold higher than the incidence in subjects without this allele. This association was then validated in $>16,000$ genotyped patients from the Heart Protection Study trial cohort. Within this group, an OR for SRM of 2.6 per copy of the ${ }^{*} 5$ allele $(P=0.004)$ was found.

The effect of the SLCO1B1 ${ }^{*}$ allele was subsequently evaluated by Voora et al. ${ }^{58}$ in the open-label STRENGTH trial, which randomized patients to ascending doses of pravastatin $(10 \rightarrow 40 \mathrm{mg})$, atorvastatin $(10 \rightarrow 80 \mathrm{mg})$, or simvastatin $(20 \rightarrow 80 \mathrm{mg})$. A candidate gene study (CYP2D6, CYP2C8, CYP2C9, CYP3A4, and $S L C O 1 B 1)$ was performed for the composite end point of selfreported muscle pain or weakness, discontinuation due to any side effect, or CK greater than three times the upper limit of normal. Only the SLCO1B1 ${ }^{\star} 5$ allele was found to be significantly associated with the end point occurring in $37 \%$ vs. $25 \%$ of allele carriers and noncarriers, respectively $(P=0.03)$. This allele displayed a gene-dosage effect $(P=0.01)$, and only simvastatin was found to be associated with the outcome.

This association was then evaluated by Donnelly et al. ${ }^{63}$ within the GO-DARTS (Genetics of Diabetes Audit and Research) community-based cohort of type 2 diabetes patients. The GO-DARTS 
Table 4 Studies evaluating pharmacogenetic associations with statin-related myopathy

\begin{tabular}{|c|c|c|c|c|c|c|c|}
\hline Study ${ }^{a}$ & $N$ & Study design & & s/alleles & Statins $^{b}$ & Sample & Results \\
\hline $\begin{array}{l}\text { Mulder } \\
\text { et al., } 2001 \\
\text { (ref. 28) }\end{array}$ & 88 & Cohort & CYP2D6 & $\begin{array}{l}\star 3, * 4, * 5, \\
\star 2 x N\end{array}$ & $\mathrm{~S}(40 \mathrm{mg})$ & Patients with high LDL & $\begin{array}{l}\text { Discontinuation for any side effect } \\
\text { was higher for those who carried two } \\
\text { reduced-function alleles; RR }=4.7\end{array}$ \\
\hline \multirow{2}{*}{$\begin{array}{l}\text { Wilke } \\
\text { et al., } 2005 \\
\text { (ref. 60) }\end{array}$} & \multirow[t]{2}{*}{137} & \multirow[t]{2}{*}{ Case-control } & СYРЗА4 & $* 1 B$ & \multirow[t]{2}{*}{ A } & \multirow[t]{2}{*}{ Patients with high LDL } & \multirow{2}{*}{$\begin{array}{l}\text { Allele frequencies were similar in } \\
\text { cases and controls. After controlling } \\
\text { for concomitant gemfibrozil and niacin } \\
\text { use, } 3 A 5 \text { genotype was associated with } \\
\text { degree of CK elevation within the case } \\
\text { cohort }(P<0.05)\end{array}$} \\
\hline & & & СYРЗА & *3 & & & \\
\hline
\end{tabular}

\begin{tabular}{|c|c|c|c|c|c|c|c|}
\hline \multirow[t]{3}{*}{$\begin{array}{l}\text { Fiegenbaum } \\
\text { et al., } 2005 \\
\text { (ref. 53) }\end{array}$} & \multirow[t]{3}{*}{116} & \multirow[t]{3}{*}{ Cohort } & $A B C B 1$ & $\begin{array}{l}1236 C>T \\
2677 G>A / T \\
\text { and } 3435 C>T\end{array}$ & \multirow[t]{3}{*}{$S$} & \multirow[t]{3}{*}{ Hyperlipidemic patients } & \multirow[t]{3}{*}{$\begin{array}{l}A B C B 1 \text { genotype was found to be } \\
\text { associated with myalgia }(P<0.05) \text {. } \\
\text { No association seen for } C Y P 3 A 4 / 5\end{array}$} \\
\hline & & & CYPЗА4 & $\star 1 B$ & & & \\
\hline & & & CYP3A5 & *3 & & & \\
\hline \multirow[t]{2}{*}{$\begin{array}{l}\text { Frudakis } \\
\text { et al., } 2007 \\
\text { (ref. 29) }\end{array}$} & \multirow[t]{2}{*}{263} & \multirow[t]{2}{*}{ Case-control } & \multicolumn{2}{|c|}{$\begin{array}{l}388 \text { Candidate genes } \\
\text { (mostly cytochrome P450) } \\
\text { SNPs }\end{array}$} & \multirow[t]{2}{*}{$S, A$} & \multirow[t]{2}{*}{$\begin{array}{l}\text { Clinically annotated and } \\
\text { deidentified samples from } \\
\text { diverse populations }\end{array}$} & \multirow{2}{*}{$\begin{array}{l}\text { Only the * } 4 \text { allele was significantly } \\
\text { associated with muscle-related side } \\
\text { effects }(O R=2.5, P<0.001) \text { in } A \\
\text { patients. Trend seen in } S \text { patients but } \\
\text { not significant }\end{array}$} \\
\hline & & & CYP2D6 & $\begin{array}{l}\star 2-* 12, * 14 \\
\star 17, \text { Dup. }\end{array}$ & & & \\
\hline \multirow{3}{*}{$\begin{array}{l}\text { Zuccaro } \\
\text { et al., } 2007 \\
\text { (ref. } 57 \text { ) }\end{array}$} & \multirow[t]{3}{*}{100} & \multirow[t]{3}{*}{ Case-control } & CYP2C9 & $\star 2, * 3$ & \multirow[t]{3}{*}{$S, F, R, A, P R$} & \multirow{3}{*}{$\begin{array}{l}\text { Patients with SRM versus } \\
\text { age- and sex-matched } \\
\text { controls }\end{array}$} & \multirow{3}{*}{$\begin{array}{l}\text { No statistically significant differences } \\
\text { in cytochrome P } 450 \text { genotypes between } \\
\text { cases and controls }\end{array}$} \\
\hline & & & & *3-*6 & & & \\
\hline & & & СУРЗАБ & *3 & & & \\
\hline \multirow{2}{*}{$\begin{array}{l}\text { SEARCH/HPS, } \\
\text { Link et al., } \\
2008 \text { (ref. } 62 \text { ) }\end{array}$} & 175 & Case-control & SLCO1B1 & $\star 1 a, * 5$ & $\mathrm{~S}(80 \mathrm{mg})$ & \multirow{2}{*}{$\begin{array}{l}\text { SEARCH trial cohort } \\
\text { HPS trial cohort }\end{array}$} & \multirow{2}{*}{$\begin{array}{l}\mathrm{RR}=4.7 \text { per copy of } \star 5\left(P<5 \times 10^{-28}\right) \\
\mathrm{RR}=2.6 \text { per copy of } \star 5(P<0.005)\end{array}$} \\
\hline & 16,664 & Case-control & SLCO1B1 & $\star 1 a, * 5$ & $\mathrm{~S}(40 \mathrm{mg})$ & & \\
\hline \multirow{5}{*}{$\begin{array}{l}\text { STRENGTH, } \\
\text { Voora } \\
\text { et al., } 2009 \\
\text { (ref. 58) }\end{array}$} & \multirow[t]{5}{*}{509} & \multirow{5}{*}{$\begin{array}{l}\text { Randomized } \\
\text { trial }\end{array}$} & CYP2D6 & $\star 4, * 10$ & \multirow[t]{5}{*}{$A, S, P R$} & \multirow[t]{5}{*}{ Patients with high LDL } & \multirow{5}{*}{$\begin{array}{l}\text { SLCO1B1*5 was significantly associated } \\
\text { with composite adverse events in } \\
\text { patients on S. Gene-dosage effect seen }\end{array}$} \\
\hline & & & & & & & \\
\hline & & & CYP2C9 & *3 & & & \\
\hline & & & СYР3А4 & $\star 1 B$ & & & \\
\hline & & & SLCO1B1 & $\star 5$ & & & \\
\hline \multirow{2}{*}{$\begin{array}{l}\text { Puccetti } \\
\text { et al., } 2010 \\
\text { (ref. 64) }\end{array}$} & \multirow[t]{2}{*}{76} & \multirow[t]{2}{*}{ Cohort } & SLCO1B1 & $\begin{array}{l}* 1 a, * 1 b, * 5 \\
* 17\end{array}$ & \multirow[t]{2}{*}{$A, R$} & \multirow[t]{2}{*}{$\begin{array}{l}\text { Patients with dyslipidemia } \\
\text { or heart disease risk }\end{array}$} & \multirow[t]{2}{*}{$\begin{array}{l}\text { * } 5 \text { Had no effect in rosuvastatin, but } \\
\text { was seen in } A(O R=2.7, P<0.001)\end{array}$} \\
\hline & & & COQ2 & rs4693075 & & & \\
\hline $\begin{array}{l}\text { Donnelly } \\
\text { et al., } 2011 \\
\text { (ref. 63) }\end{array}$ & 4,141 & Cohort & SLCO1B1 & $\begin{array}{l}* 1 a, * 1 b, * 5 \\
* 17\end{array}$ & $\begin{array}{l}\text { A, F, L, PR, } \\
P T, S\end{array}$ & $\begin{array}{l}\text { Scottish diabetics who had } \\
\text { filled at least two statin } \\
\text { scripts between } 1990 \text { and } \\
2008\end{array}$ & $\begin{array}{l}\text { * } 5 \text { Was associated with greater } \\
\text { intolerance }(\mathrm{OR}=2.05, P=0.043) \text {; } \\
\text { high-function variant, * } 1 B \text {, was } \\
\text { associated with lower intolerance }\end{array}$ \\
\hline $\begin{array}{l}\text { Brunham } \\
\text { et al., } 2011 \\
\text { (ref. 65) }\end{array}$ & 109 & Case-control & SLCO1B1 & $* 1 a, * 5$ & $S, A, P R, R$ & $\begin{array}{l}\text { Dutch patients with severe } \\
\text { myopathy and matched } \\
\text { controls }\end{array}$ & $\begin{array}{l}\text { * } 5 \text { Was significantly associated with } \\
\text { myopathy in } S \text { patients }(O R=2.3 \text { per } \\
\text { allele, } P<0.05) \text { but not in patients on } A\end{array}$ \\
\hline $\begin{array}{l}\text { Marciante } \\
\text { et al., } 2011 \\
\text { (ref. 67) }\end{array}$ & 917 & Case-control & $\begin{array}{l}\text { GWAS anc } \\
\text { analysis (C } \\
\text { UGT1A3, }\end{array}$ & $\begin{array}{l}\text { candidate gene } \\
\text { P2C8, UGT1A1, } \\
\text { d SLCO1B1) }\end{array}$ & C & $\begin{array}{l}\text { Cerivastatin-related } \\
\text { rhabdomyolysis cases and } \\
\text { matched controls }\end{array}$ & $\begin{array}{l}\text { Association seen between } C \text {-induced } \\
\text { rhabdomyolysis and } * 5(O R=1.89 \text {, } \\
P=0.002) \text {. In functional studies, variant } \\
\text { showed }-40 \% \text { change in transport as } \\
\text { compared with reference }(P<0.001)\end{array}$ \\
\hline $\begin{array}{l}\text { Santos } \\
\text { et al., } 2011 \\
\text { (ref. 66) }\end{array}$ & 143 & Cohort & SLCO1B1 & $\begin{array}{l}521 T>C \text { and } \\
388 A>G\end{array}$ & A & $\begin{array}{l}\text { Individuals on atorvastatin } \\
\text { therapy }\end{array}$ & $\begin{array}{l}\text { No association between SNPs and } \\
\text { A-related myalgia or abnormal CK }\end{array}$ \\
\hline $\begin{array}{l}\text { Marshfield/ } \\
\text { SEARCH } \\
\text { meta-analysis, } \\
2013 \text { (ref. 61) }\end{array}$ & $\begin{array}{l}72 \\
100\end{array}$ & Case-control & GATM & $\begin{array}{l}\text { rs9806699, } \\
\text { rs1719247, } \\
\text { rs } 1346268\end{array}$ & $S$ & $\begin{array}{l}\text { Population- (Marshfield) } \\
\text { and trial- (SEARCH) based } \\
\text { cohort of patients on } \\
\text { simvastatin }\end{array}$ & $\begin{array}{l}\text { Meta-analysis of two cohorts showed an } \\
\text { OR of } 0.60 \text { for myopathy as defined by } \\
\text { CK elevation and report of pain } \\
\left(95 \% \mathrm{Cl}: 0.45-0.81, P=6 \times 10^{-4}\right)\end{array}$ \\
\hline
\end{tabular}

$\mathrm{Cl}$, confidence interval; CK, creatine kinase; GWAS, genome-wide association study; HPS, Heart Protection Study; LDL, low-density lipoprotein; OR, odds ratio; RR, relative risk; SEARCH, Study of the Effectiveness of Additional Reductions in Cholesterol and Homocysteine; SNP, single-nucleotide polymorphism; SRM, statin-related myopathy.

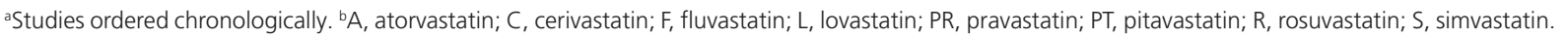


study population was an observational cohort of $>4,000$ patients with diabetes in the Scottish town of Tayside. The database for this study contains genotypes, prescriptions, laboratory results, and other medical information related to diabetes care from 1990 to the present. This study was aimed at evaluating low-grade events; therefore, cases with CK greater than three times the upper limit of normal were excluded. This study replicated the association of the $S L C O 1 B 1^{*} 5$ allele with statin intolerance, defined here as a combination of relevant statin prescription changes or discontinuation and indicative CK laboratory test results $(\mathrm{OR}=2.05$, 95\% confidence interval: $1.02-4.09, P=0.04$ ).

Smaller studies (by Puccetti et al., ${ }^{64}$ Brunham et al., ${ }^{65}$ and Santos et al. ${ }^{66}$ ) have investigated SLCO1B1's effect across the statin class, suggesting a gradient of effect across statin types. Marciante et al. ${ }^{67}$ evaluated the effect of this transporter on SRM associated with cerivastatin, which was recalled from the market in 2001 due to its unacceptably high rate of rhabdomyolysis. This study compared a cohort of 185 cerivastatin-related rhabdomyolysis cases with frequency-matched statin users from the Cardiovascular Health Study $(n=374)$ and the Vascular Health Study $(n=358)$. Both a genome-wide association study and a candidate gene (CYP2C8, UGT1A1, UGT1A3, and SLCO1B1) analysis were conducted, with only $S L C O 1 B 1$ showing a significant association in permutation testing $(\mathrm{OR}=1.89, P=0.002)$.

The body of evidence surrounding the association of SRM with SLCO1B1 is strong enough that dosing algorithms have been proposed for clinical use. ${ }^{68}$ The Clinical Pharmacogenomics Implementation Consortium has drafted a dosing algorithm for how SLCO1B1 55 genotype could be used clinically to personalize a patient's simvastatin dose. ${ }^{68}$ To date, however, professional societies such as the American College of Cardiology have not weighed in on whether SLCO1B1 testing is ready for clinical adoption.

\section{Efflux transporters: $A B C B 1$ and $A B C G 2$}

Although it is biologically plausible that the efflux transporters $A B C B 1$ and $A B C G 2$ would have an influence on statin concentrations and subsequent myopathy, the nature of their association with these outcomes has not been as well characterized as that for the influx transporter OATP1B1. Although pharmacokinetic studies have shown that functional variations in these two genes may lead to higher plasma AUC levels across the statin class, ${ }^{54-56,69-73}$ only one study has evaluated these genes in relation to safety end points. In a cohort study conducted by Fiegenbaum et al. ${ }^{53}$ of 116 patients treated for 6 months with $20 \mathrm{mg}$ simvastatin, 15 patients had to discontinue early due to myalgia. In a nested case-control analysis of data from this study, a haplotype formed from ABCB1 1236T, 2677non-G, and $3435 \mathrm{~T}$ alleles was significantly less common in those without myalgia. ${ }^{53}$ Although this study provides an interesting data point, its results will need to be replicated and in larger populations before it is considered for adoption in clinical practice.

\section{DISCUSSION}

This review focused on the ADME characteristics of statins and on genetic loci that have been shown to have consistent pharmacokinetic and subsequent clinical influence (via medically defined myopathy events), which included loci encoding cytochrome P450 enzymes (CYP2D6, CYP3A4, and CYP3A5), a mitochondrial enzyme (GATM), an influx transporter (SLCO1B1), and efflux transporters ( $A B C B 1$ and $A B C G 2$ ). This relationship is strongest for simvastatin and appears to occur on a spectrum that follows the lipophilicity of this class, with more lipophilic agents (simvastatin, cerivastatin, lovastatin, and atorvastatin) more likely to cause symptoms than hydrophilic agents (pravastatin, rosuvastatin, and fluvastatin). ${ }^{8}$ It has been suggested that this might be due to the fact that lipophilic agents are more likely to penetrate into muscle tissue, thereby amplifying the myopathic effect. ${ }^{74}$ Of course, the effect of dose and potency is independent of the lipophilicity. Although higher doses of implicated statins do carry higher risk than lower doses, there is no discernible trend in myopathy effect and relative potency as measured by low-density-lipoprotein-lowering ability. An example of this can be seen with rosuvastatin, which has generally high potency but low myopathy risk.

All of these genes have clear biological plausibility for an effect on the pharmacokinetics and subsequent myopathy of statins, yet their genetic risk remains to be defined well based on the existing evidence. Among all the genes included in this review, SRM appears to be strongly and consistently associated only with variants in SLCO1B1, especially for simvastatin, for which the relationship appears to be the strongest.

Although there is strong biological plausibility for an association between genetic variation at cytochrome P450 loci and SRM, the evidence is mixed and does not point to a clear and consistent association. Studies of this association are limited by studies with small sample sizes and by the use of mixed statin-patient cohorts. Individual statins are primarily metabolized by different cytochrome P450 enzymes, so, by including multiple statins in a test for association with SRM and a single locus, these studies are probably diluting any potential association. Future studies that are adequately powered and focused on a single statin may resolve some of these ambiguities. Importantly, recent evidence has suggested that a SNP (rs1719247) in the GATM gene appears to represent a protective factor for SRM. ${ }^{61}$ Although this finding has not yet been replicated, it presents a novel and important finding that merits further research.

The evidence for an association between the ${ }^{\star} 5$ allele of SLCO1B1 and SRM is strong and convincing, especially for simvastatin, for which this relationship appears to be strongest. In fact, every study identified in this analysis showed a clear association between this locus and simvastatin-related myopathy. This has clear public health implications because simvastatin has recently had dosage limitations imposed by the Food and Drug Administration due to its myopathy risk. ${ }^{6}$ Despite these limitations, simvastatin comprises an effective and inexpensive therapy, and in those at low risk for myopathy, the benefits clearly outweigh the harms. However, it is still unclear whether 
the use of prospective genotyping will be cost effective because to date no studies on this question have been completed.

This review is limited by the variability in the studies that are available for evaluation. First, the diversity in how outcomes for SRM were defined in this analysis makes any quantitative synthesis of this information difficult, precluding conducting a meta-analysis of these results. Next, for some pharmacogenomics associations, there may be only one relevant study, which makes drawing any definitive conclusions difficult. Furthermore, the majority of these studies are based on candidate SNPs, which limits the associations that can be tested to those that were defined a priori. Finally, this article was limited in scope to associations of genes with known ADME significance. Although it is known that hereditary conditions such as McArdle disease predispose patients to higher rates of SRM, these conditions are extremely rare and therefore do not lend themselves to preemptive screening to avoid SRM.

Although SRM may not always be dangerous enough to cause severe disability, it has important consequences for treatment discontinuation and adherence. Because elevated levels of lowdensity-lipoprotein cholesterol are almost entirely asymptomatic, side effects such as SRM can diminish patient adherence and, subsequently, the overall efficacy of treatment. It has been shown that side effects are important causes of both treatment discontinuation and low adherence. ${ }^{11-13}$ Furthermore, of those discontinuing treatment due to a side effect, many do so without consulting their physicians. ${ }^{14}$

Adjusting statin therapy in response to intolerance is currently standard of care. ${ }^{75}$ Current joint guidelines from the American College of Cardiology, the American Heart Association, and the National Heart, Lung, and Blood Institute suggest treatment adjustments to alleviate myopathy in patients who still need cholesterol lowering. Genotyping may present an opportunity for personalizing and adjusting therapy before intolerance occurs, although it is still unclear whether it will become standard of care in the clinic.

\section{Conclusion}

This review evaluated the evidence for a genetic contribution to SRM, the most common side effect in this widely used class of drugs. Among all the loci identified, only the ${ }^{\star 5}$ allele of SLCO1B1 was strongly and consistently associated with the onset of myopathy (Table 4). Although the evidence for this association is clear and consistent, it is still unclear whether the use of prospective genotyping and subsequent statin personalization will be cost effective. Other genes included in this review (CYP2D6, CYP3A4/5, GATM, ABCB1, and ABCG2) have either only preliminary or contradictory evidence of an association. As previously mentioned, this effect appears in a gradient across the statin types in the class, in addition to showing a clear doseresponse relationship. Although yet to be tested, this gradient of effect generates the hypothesis that prospective genotyping might provide an opportunity for drug selection via personalized safety risk before treatment initiation. Studies evaluating the clinical utility of this approach are necessary to determine whether this will in fact improve patient outcomes.

\section{ACKNOWLEDGMENT}

This work was supported by National Institutes of Health grant U01GM092676 (principal investigators: K.E.T. and Wylie Burke).

\section{DISCLOSURE}

The authors declare no conflict of interest.

\section{REFERENCES}

1. Smith SC, Jr., Blair SN, Bonow RO, et al. AHAVACC Guidelines for Preventing Heart Attack and Death in Patients With Atherosclerotic Cardiovascular Disease: 2001 update. A statement for healthcare professionals from the American Heart Association and the American College of Cardiology. J Am Coll Cardiol 2001;38:1581-1583.

2. Baigent C, Blackwell L, Emberson J, et al.; Cholesterol Treatment Trialists' (CTT) Collaboration. Efficacy and safety of more intensive lowering of LDL cholesterol: a meta-analysis of data from 170,000 participants in 26 randomised trials. Lancet 2010;376:1670-1681.

3. Mihaylova B, Emberson J, Blackwell L, et al.; Cholesterol Treatment Trialists' (CTT) Collaborators. The effects of lowering LDL cholesterol with statin therapy in people at low risk of vascular disease: meta-analysis of individual data from 27 randomised trials. Lancet 2012;380:581-590.

4. Informatics IIfH. The Use of Medicines in the United States: Review of 2011. 2012. http://www.imshealth.com/ims/Global/Content/Insights/IMS\%20 Institute $\% 20$ for $\% 20$ Healthcare $\% 20$ Informatics/IHII_Medicines_in_U.S_ Report_2011.pdf. Accessed 13 August 2012

5. Staffa JA, Chang J, Green L. Cerivastatin and reports of fatal rhabdomyolysis. NEngl J Med 2002;346:539-540.

6. Egan A, Colman E. Weighing the benefits of high-dose simvastatin against the risk of myopathy. N Engl J Med 2011;365:285-287

7. US Food and Drug Administration. FDA Drug Safety Communication: Ongoing safety review of high-dose Zocor (simvastatin) and increased risk of muscle injury, 2010. http://www.fda.gov/Drugs/DrugSafety/ PostmarketDrugSafetyInformationforPatientsandProviders/ucm204882.htm. Accessed 16 June 2011.

8. Bruckert E, Hayem G, Dejager S, Yau C, Bégaud B. Mild to moderate muscular symptoms with high-dosage statin therapy in hyperlipidemic patients-the PRIMO study. Cardiovasc Drugs Ther 2005;19:403-414.

9. Eckel RH. Approach to the patient who is intolerant of statin therapy. J Clin Endocrinol Metab 2010;95:2015-2022.

10. Joy TR, Hegele RA. Narrative review: statin-related myopathy. Ann Intern Med 2009;150:858-868.

11. Mann DM, Woodward M, Muntner P, Falzon L, Kronish I. Predictors of nonadherence to statins: a systematic review and meta-analysis. Ann Pharmacother 2010;44:1410-1421.

12. Mann DM, Allegrante JP, Natarajan S, Halm EA, Charlson M. Predictors of adherence to statins for primary prevention. Cardiovasc Drugs Ther 2007;21:311-316.

13. Brown MT, Bussell JK. Medication adherence: WHO cares? Mayo Clin Proc 2011;86:304-314.

14. Cohen JD, Brinton EA, Ito MK, Jacobson TA. Understanding Statin Use in America and Gaps in Patient Education (USAGE): an internet-based survey of 10,138 current and former statin users. J Clin Lipido/ 2012;6:208-215.

15. Josan K, Majumdar SR, McAlister FA. The efficacy and safety of intensive statin therapy: a meta-analysis of randomized trials. CMAJ 2008;178:576-584.

16. Ghatak A, Faheem O, Thompson PD. The genetics of statin-induced myopathy Atherosclerosis 2010;210:337-343.

17. Hermann M, Bogsrud MP, Molden E, et al. Exposure of atorvastatin is unchanged but lactone and acid metabolites are increased several-fold in patients with atorvastatin-induced myopathy. Clin Pharmacol Ther 2006;79:532-539.

18. Laaksonen R. On the mechanisms of statin-induced myopathy. Clin Pharmacol Ther 2006;79:529-531.

19. Song K, Mosteller M, Lawson M, Nelson MR. Practical limitations to estimating heritability in pharmacogenetic studies. Pharmacogenomics 2013;14:851-852.

20. Marshall SL, Guennel T, Kohler J, Man M, Fossceco S. Estimating heritability in pharmacogenetic studies. Pharmacogenomics 2013;14:369-377. 
21. Furge LL, Guengerich FP. Cytochrome P450 enzymes in drug metabolism and chemical toxicology: An introduction. Biochem Mol Biol Educ 2006;34:66-74.

22. Guengerich FP. Cytochrome p450 and chemical toxicology. Chem Res Toxicol 2008:21:70-83.

23. Williams $D$, Feely J. Pharmacokinetic-pharmacodynamic drug interactions with HMG-CoA reductase inhibitors. Clin Pharmacokinet 2002;41:343-370.

24. CYP2D6 allele nomenclature. The Human Cytochrome P450 (CYP) Allele Nomenclature Database 2014. http://www.cypalleles.ki.se/cyp2d6.htm. Accessed 4 February 2014.

25. Vermes A, Vermes I. Genetic polymorphisms in cytochrome P450 enzymes: effect on efficacy and tolerability of HMG-CoA reductase inhibitors. Am J Cardiovasc Drugs 2004;4:247-255.

26. Li J, Wang X, Zhang Z, et al. Statin therapy correlated CYP2D6 gene polymorphism and hyperlipidemia. Current Medical Res Opin 2014;30: 223-228.

27. Yin OQ, Mak VW, Hu M, Fok BS, Chow MS, Tomlinson B. Impact of CYP2D6 polymorphisms on the pharmacokinetics of lovastatin in Chinese subjects. Eur J Clin Pharmacol 2012;68:943-949.

28. Mulder AB, van Lijf HJ, Bon MA, et al. Association of polymorphism in the cytochrome CYP2D6 and the efficacy and tolerability of simvastatin. Clin Pharmacol Ther 2001;70:546-551.

29. Frudakis TN, Thomas MJ, Ginjupalli SN, Handelin B, Gabriel R, Gomez HJ. CYP2D6*4 polymorphism is associated with statin-induced muscle effects. Pharmacogenet Genomics 2007;17:695-707.

30. Kim K, Johnson JA, Derendorf H. Differences in drug pharmacokinetics between East Asians and Caucasians and the role of genetic polymorphisms. J Clin Pharmacol 2004;44:1083-1105.

31. Lamba JK, Lin YS, Schuetz EG, Thummel KE. Genetic contribution to variable human CYP3A-mediated metabolism. Adv Drug Deliv Rev 2002;54: 1271-1294.

32. Lamba JK, Lin YS, Thummel K, et al. Common allelic variants of cytochrome P4503A4 and their prevalence in different populations. Pharmacogenetics 2002;12:121-132.

33. Hsieh KP, Lin YY, Cheng CL, et al. Novel mutations of CYP3A4 in Chinese. Drug Metab Dispos 2001;29:268-273.

34. Walker AH, Jaffe JM, Gunasegaram $S$, et al. Characterization of an allelic variant in the nifedipine-specific element of CYP3A4: ethnic distribution and implications for prostate cancer risk. Mutations in brief no. 191. Online. Hum Mutat 1998;12:289.

35. Ball SE, Scatina J, Kao J, et al. Population distribution and effects on drug metabolism of a genetic variant in the $5^{\prime}$ promoter region of CYP3A4. Clin Pharmacol Ther 1999;66:288-294.

36. Kuehl P, Zhang J, Lin Y, et al. Sequence diversity in CYP3A promoters and characterization of the genetic basis of polymorphic CYP3A5 expression. Nat Genet 2001;27:383-391.

37. García-Martín E, Martínez C, Pizarro RM, et al. CYP3A4 variant alleles in white individuals with low CYP3A4 enzyme activity. Clin Pharmacol Ther 2002;71:196-204.

38. Paris PL, Kupelian PA, Hall JM, et al. Association between a CYP3A4 genetic variant and clinical presentation in African-American prostate cancer patients. Cancer Epidemiol Biomarkers Prev 1999;8:901-905.

39. Sata F, Sapone A, Elizondo G, et al. CYP3A4 allelic variants with amino acid substitutions in exons 7 and 12: evidence for an allelic variant with altered catalytic activity. Clin Pharmacol Ther 2000;67:48-56.

40. Wang D, Guo Y, Wrighton SA, Cooke GE, Sadee W. Intronic polymorphism in CYP3A4 affects hepatic expression and response to statin drugs. Pharmacogenomics J 2011;11:274-286.

41. Sadee W. Gene-gene-environment interactions between drugs, transporters, receptors, and metabolizing enzymes: Statins, SLCO1B1, and CYP3A4 as an example. J Pharm Sci 2013;102:2924-2929.

42. Hustert $E$, Haberl M, Burk O, et al. The genetic determinants of the CYP3A5 polymorphism. Pharmacogenetics 2001;11:773-779.

43. Paine MF, Khalighi M, Fisher JM, et al. Characterization of interintestinal and intraintestinal variations in human CYP3A-dependent metabolism. J Pharmacol Exp Ther 1997;283:1552-1562.

44. Ballard KD, Thompson PD. Does reduced creatine synthesis protect against statin myopathy? Cell Metab 2013;18:773-774.

45. Oshiro C, Mangravite L, Klein T, Altman R. PharmGKB very important pharmacogene: SLCO1B1. Pharmacogenet Genomics 2010;20:211-216.

46. Tirona RG, Leake BF, Merino G, Kim RB. Polymorphisms in OATP-C: identification of multiple allelic variants associated with altered transport activity among European- and African-Americans. J Biol Chem 2001;276:35669-35675.
47. Mwinyi J, Köpke K, Schaefer M, Roots I, Gerloff T. Comparison of SLCO1B1 sequence variability among German, Turkish, and African populations. Eur J Clin Pharmacol 2008;64:257-266.

48. Nozawa T, Nakajima M, Tamai I, et al. Genetic polymorphisms of human organic anion transporters OATP-C (SLC21A6) and OATP-B (SLC21A9): allele frequencies in the Japanese population and functional analysis. J Pharmacol Exp Ther 2002;302:804-813.

49. Nishizato Y, leiri I, Suzuki H, et al. Polymorphisms of OATP-C (SLC21A6) and OAT3 (SLC22A8) genes: consequences for pravastatin pharmacokinetics. Clin Pharmacol Ther 2003;73:554-565.

50. Ho WF, Koo SH, Yee JY, Lee EJ. Genetic variations of the SLCO1B1 gene in the Chinese, Malay and Indian populations of Singapore. Drug Metab Pharmacokinet 2008;23:476-482.

51. Couvert $P$, Giral $P, D e j a g e r ~ S$, et al. Association between a frequent allele of the gene encoding OATP1B1 and enhanced LDL-lowering response to fluvastatin therapy. Pharmacogenomics 2008;9:1217-1227.

52. Pasanen MK, Backman JT, Neuvonen PJ, Niemi M. Frequencies of single nucleotide polymorphisms and haplotypes of organic anion transporting polypeptide 1B1 SLCO1B1 gene in a Finnish population. Eur J Clin Pharmacol 2006;62:409-415.

53. Fiegenbaum $M$, da Silveira FR, Van der Sand CR, et al. The role of common variants of $A B C B 1, C Y P 3 A 4$, and CYP3A5 genes in lipid-lowering efficacy and safety of simvastatin treatment. Clin Pharmacol Ther 2005;78:551-558.

54. Keskitalo JE, Kurkinen KJ, Neuvonen M, Backman JT, Neuvonen PJ, Niemi M. No significant effect of $A B C B 1$ haplotypes on the pharmacokinetics of fluvastatin, pravastatin, lovastatin, and rosuvastatin. Br J Clin Pharmacol 2009;68:207-213.

55. Keskitalo JE, Kurkinen KJ, Neuvoneni PJ, Niemi M. ABCB1 haplotypes differentially affect the pharmacokinetics of the acid and lactone forms of simvastatin and atorvastatin. Clin Pharmacol Ther 2008;84:457-461.

56. Keskitalo JE, Zolk O, Fromm MF, Kurkinen KJ, Neuvonen PJ, Niemi M. ABCG2 polymorphism markedly affects the pharmacokinetics of atorvastatin and rosuvastatin. Clin Pharmacol Ther 2009;86:197-203.

57. Zuccaro P, Mombelli G, Calabresi L, Baldassarre D, Palmi I, Sirtori CR. Tolerability of statins is not linked to CYP450 polymorphisms, but reduced CYP2D6 metabolism improves cholesteraemic response to simvastatin and fluvastatin. Pharmacol Res 2007;55:310-317.

58. Voora D, Shah SH, Spasojevic I, et al. The SLCO1B1*5 genetic variant is associated with statin-induced side effects. J Am Coll Cardiol 2009;54: 1609-1616.

59. Park JE, Kim KB, Bae SK, Moon BS, Liu KH, Shin JG. Contribution of cytochrome P450 3A4 and 3 A5 to the metabolism of atorvastatin. Xenobiotica 2008;38:1240-1251.

60. Wilke RA, Moore JH, Burmester JK. Relative impact of CYP3A genotype and concomitant medication on the severity of atorvastatin-induced muscle damage. Pharmacogenet Genomics 2005;15:415-421.

61. Mangravite LM, Engelhardt BE, Medina MW, et al. A statin-dependent QTL for GATM expression is associated with statin-induced myopathy. Nature 2013;502:377-380

62. Link E, Parish S, Armitage J, et al. SLCO1B1 variants and statin-induced myopathy--a genomewide study. New Eng J Med 2008;359:789-799.

63. Donnelly LA, Doney AS, Tavendale R, et al. Common nonsynonymous substitutions in SLCO1B1 predispose to statin intolerance in routinely treated individuals with type 2 diabetes: a go-DARTS study. Clin Pharmacol Ther 2011;89:210-216.

64. Puccetti L, Ciani F, Auteri A. Genetic involvement in statins induced myopathy. Preliminary data from an observational case-control study. Atherosclerosis 2010;211:28-29.

65. Brunham LR, Lansberg PJ, Zhang L, et al. Differential effect of the rs 4149056 variant in SLCO1B1 on myopathy associated with simvastatin and atorvastatin. Pharmacogenomics J 2012;12:233-237.

66. Santos PC, Gagliardi AC, Miname MH, et al. SLCO1B1 haplotypes are not associated with atorvastatin-induced myalgia in Brazilian patients with familial hypercholesterolemia. Eur J Clin Pharmacol 2012;68:273-279.

67. Marciante KD, Durda JP, Heckbert SR, et al. Cerivastatin, genetic variants, and the risk of rhabdomyolysis. Pharmacogenet Genomics 2011;21:280-288.

68. Wilke RA, Ramsey LB, Johnson SG, et al.; Clinical Pharmacogenomics Implementation Consortium (CPIC). The clinical pharmacogenomics implementation consortium: CPIC guideline for SLCO1B1 and simvastatininduced myopathy. Clin Pharmacol Ther 2012;92:112-117.

69. Keskitalo JE, Pasanen MK, Neuvonen PJ, Niemi M. Different effects of the ABCG2 $c .421 C>A$ SNP on the pharmacokinetics of fluvastatin, pravastatin and simvastatin. Pharmacogenomics 2009;10:1617-1624. 
70. Schnepf R, Zolk O. Effect of the ATP-binding cassette transporter ABCG2 on pharmacokinetics: experimental findings and clinical implications. Expert Opin Drug Metab Toxicol 2013;9:287-306.

71. Zhou Q, Chen QX, Ruan ZR, Yuan H, Xu HM, Zeng S. CYP2C9*3(1075A > C), $A B C B 1$ and SLCO1B1 genetic polymorphisms and gender are determinants of inter-subject variability in pitavastatin pharmacokinetics. Pharmazie 2013:68:187-194.

72. Zhou Q, Ruan ZR, Yuan H, Xu DH, Zeng S. ABCB1 gene polymorphisms, $A B C B 1$ haplotypes and $A B C G 2 c .421 C>A$ are determinants of inter-subject variability in rosuvastatin pharmacokinetics. Pharmazie 2013;68:129-134.
73. Zhou Q, Ruan ZR, Yuan H, Zeng S. CYP2C9*3(1075A>C), MDR1 G2677T/A and MDR1 C3435T are determinants of inter-subject variability in fluvastatin pharmacokinetics in healthy Chinese volunteers. Arzneimittelforschung 2012;62:519-524.

74. Sathasivam S, Lecky B. Statin induced myopathy. BMJ 2008;337:a2286

75. Pasternak RC, Smith SC Jr, Bairey-Merz CN, Grundy SM, Cleeman JI, Lenfant C; American College of Cardiology; American Heart Association National Heart, Lung and Blood Institute. ACC/AHA/NHLBI clinical advisory on the use and safety of statins. J Am Coll Cardiol 2002;40: 567-572. 